\title{
Achieving human security for migrants: the limits of state policies and migration-development initiatives
}

\author{
Benjamin A. San Jose* ${ }^{*}$
}

\author{
*Correspondence: \\ benjasj25@gmail.com \\ De La Salle University, Manila, \\ Philippines
}

\begin{abstract}
The Philippines is one of the top migrant sending countries and is often lauded as a model migrant country due to its skilled migrant labor force, high remittance rates and forward-thinking government policies. However, it is often criticized for its policies of exploitative labor migrant export, its dependency to migrant remittances, and its failure to offer migrant protection. In recent years, scholars and policy makers have suggested using human security as an approach to address the challenges of migration. By bringing the focus away from the state to becoming people-centered, human security aims to address the problems of statelessness, the lack of migrant protection, human rights, and offers long-term solutions to migration. Since the Philippines is highly dependent on migrant labor and is in the forefront of promoting migrant conditions in the international arena, some relevant questions can be raised: what are the role and benefits of using a human security approach for migrants? How does the Philippines attempt to secure human security for its migrants? Has the Philippines achieved human security for its migrants? This paper argues that as the Philippines grew more dependent on labor migration, human security for migrants is attempted by the state through an institutionalized set of policies and assumptions. The promise of migrant welfare and human security is premised on the following points: creating better policies and institutionalizing migrant state agencies, creating national laws together with bilateral and multilateral agreements on migration and in recent years, and the promotion of migration and development initiatives. While these attempts may hold promise, they suffer from limitations on implementation and sustainability. In the final analysis, human security can only be achieved by working towards a national dialogue on migration where stakeholders from the state, civil society organizations, and migrant groups participate in the national debate on the future of migration. Only by reaching a national dialogue on responsive and long-term policies that are grounded in human security can the country go beyond the view that migration and development policies are a catch-all panacea to the problems of migrant protection and long-term economic development in the homeland.
\end{abstract}

Keywords: Migration policy, Human security, Migration and development, Philippines

\section{Background}

The Philippines is one of the top migrant sending countries in the world, and with $10 \%$ of its population living and working abroad, migration plays a big role in contemporary 
Philippine social life. Often lauded as a model migrant country due to its skilled migrant labor force, high remittance rates, and its forward-thinking government policies, it is not without its critics. Activists often criticized the state for its policies of exploitative labor migrant export, its dependency on migrant remittances, and its failure to offer migrant protection. And yet, the Philippines is not alone in experiencing the positive and negative effects of our globalized "age of migration" (Castles et al. 2014). Both migrant receiving and sending countries now consider migration as one of the main challenges in our globalized world.

In recent years, scholars and policy makers have suggested using human security as an approach to address the challenges of migration. By bringing the focus away from the state and into the human dimension of migration, human security aims to address the problems of statelessness, lack of migrant protection and migrant human rights, and long-term solutions to the demographic pressures of migration at both the sending and receiving states. Since the Philippines is highly dependent on migrant labor and its state agencies is in the forefront of promoting migrant conditions in the international arena, some relevant questions can be raised: what is the role and benefits of using a human security approach for migrants? How does the Philippines guarantee human security for its migrants? Has the Philippine state achieved human security for its migrants?

This paper argues that as the Philippines grew more dependent on labor migration, the state attempts to achieve human security for migrants through an institutionalized set of policies and assumptions. The promise of migrant welfare and human security is premised on the following points: creating better policies and institutionalizing migrant state agencies, creating national laws together with bilateral and multilateral agreements on migration, and in recent years, the promotion of migration and development initiatives. While these attempts may hold promise, they suffer from limitations on their implementation and sustainability. In the final analysis, human security can only be achieved by working towards creating a national dialogue on migration: where stakeholders from the state, civil society organizations, and migrant groups participate in the national debate regarding the future of migration. Through a national dialogue that aims to foster participation towards consensus, it is only then that responsive and long-term policies grounded in human security can go beyond the view that migration and development policies are a catch-all panacea to the problems of migrant protection and long-term economic development in the homeland.

The next section discusses the research design of the study and presents the framework of the nexus of human security in migration studies. This is followed by a theoretical and substantive discussion on the role of human security in Philippine migration policies and how, through its institutionalized policies, the state promotes its human security agenda. This section also shows the limits of human security initiatives and how these can be addressed by the working towards a national dialogue on migration. The paper ends by analyzing the major themes from the various case studies and reiterating the importance of reaching a national dialogue to achieve human security for migration policy making. 


\section{Theoretical framework and methods}

Initially developed by Sadako Ogata and Amartya Sen as an alternative approach to issues related to development, human security has gone a long way since it was adopted by the United Nations under the specially created Commission on Human Security. Human security is quite different from traditional security or national security in that it is concerned with the individual and the community rather than the state. As such, it is more "people centered" and employs a two-pronged strategy that focuses on protection and empowerment (Commission on Human Security 2003). Although there have been criticisms that argue that human security cannot replace state-centered or traditional security, its adherents argue that it does not aim to replace traditional state security. Rather, it aims to enhance it through its more people centered approach (Graham and Poku 2000). Ogata explains,

I wish to emphasize that the task of the challenge to focus on the security of the people is not to replace state security.... However, it does seem important to me to attempt a paradigm shift from the traditional resort to the state as the provider of security. In turning to the people themselves to safeguard human lives from critical persuasive threats and to promote the fulfilment of their dignity, the fundamental security of the state is reinforced (2002).

While human security is still mostly used by states in promoting their foreign policy goals and by international organizations as a paradigm for understanding international development, it has been introduced as an ideal approach to understand and address the problems of international migration since it goes beyond the limits of state-oriented policies. In discussing the human security framework in the context of international migration, several scholars have pointed out its advantages.

First, as a people-centered approach, human security goes beyond the limits imposed by problems of state sovereignty, border control, citizenship rights, and statelessness (Vietti and Scribner 2013). Edwards, in discussing the case study of stateless refugees and political migrants, explains: "the people-centered focus of human security, irrespective of one's attachment or allegiance to the state, is conceptually powerful for non-citizens. Second, it is also powerful because the application of international human rights law has at times been bogged down in distinctions between nationals and non-nationals, with the latter rarely enjoying the same level of human rights protection as the former" (2010: 39). Third, scholars highlight how human security can be beneficial for all kinds of migrants, whether they be contractual laborers, permanent migrants, undocumented or political refugees. Lastly, in assessing the potential of human security, Edwards argues that at the minimum, it can become a rhetorical impetus for joint action, and at best, it can present new ways to think about problems related to migrant protection (2010:4).

While most scholars discuss the limits of state-centric migration policies and the potential of human security to address the problems brought by a state-level focus on migration (Vietti and Scribner 2013; Graham and Poku 2000; Truong and Gasper 2011), most states and state migration agencies have not used human security as an explicit framework to analyze and promote its migration policies. As such, while the literature have been quick to point on the potential of human security for creating more humane migration policies, and while some states have adopted a people-centered approach on 
migration policy making, states have not labeled their policies as following a human security framework on migration.

Thus, human security on migration is seen as a novel approach but is not yet considered mainstream since it is still used mainly in the realm of development and foreign policy making. Indeed, there have been limited substantive studies on how human security is currently being used by government agencies, civil society groups, and migrant communities. This paper attempts to contribute to the growing body of studies on migration and human security by focusing on the case of the Philippines. By using qualitative methods and analysis, this paper presents case studies on how the state attempts to adopt and achieve human security for its migrants. In particular, this paper gives special focus to the emergence of migration and development approaches to achieve human security, and gives an analysis of its long-term implications for migrant protection and development.

\section{Results and discussion}

\section{Attempts on human security through institutionalized migration policies}

With $10 \%$ of the Philippine population living and working abroad, the socio-political and economic impact of migration can easily be discerned. As of 2011, there were 9 million migrant Filipinos, $47 \%$ of whom are permanent migrants in the United States, Canada, and Australia. $43 \%$, meanwhile, are temporary or contractual labor migrants, most of whom work in the Middle East and East Asia. $10 \%$ of these are undocumented and include those who extend their stay in various destination countries or are conflict refugees in nearby Malaysia due to the armed conflict in the Southern Philippines (POEA 2010).

In looking back at the evolution of Philippine migration policy, the state mostly applied traditional state-centric policies that focused on the role of labor migration to curb unemployment and to boost much needed remittances. Indeed, migrant rights and their labor conditions were not initially emphasized. While the state's policies on the export of labor started as a stopgap solution to the balance of payment problems and growing unemployment during the Marcos regime of the 1970s, succeeding administrations have inherited the labor export apparatus (Guevarra 2010; Rodriguez 2010; Tyner 2000 ) and have continued and expanded labor migration through the years.

As the figures show, remittances play a key factor in the continuation of labor migrant export, which by 2013 rose to US\$21 billion (World Bank 2011). This figure is very high compared to the total overseas development assistance and foreign direct investment rates that only accounted for US $\$ 0.1$ and US $\$ 1.4$ billion, respectively. Indeed, remittances have been so important to both the state and the families of migrants in the homeland. They account for the rise of the retail and real-estate industry since the 1980s, and have been one of the key political reasons why succeeding administrations have survived the political and economic shortcomings through their administrations (San Jose 2008). While the state recognized the value of labor migration, it was only during the 1990s that the state, through the pressure of civil society organizations started considering the conditions and rights of migrants.

As the state grew more dependent on the benefits of labor migration, its socio-political costs were also beginning to be felt. As such, succeeding administrations from Aquino 
to Ramos began to emphasize migrant protection. While the state attempts to become more people-centric, the state has not explicitly adopted the term "Human Security" for its migration policies. In fact, its state-centric bias is evidenced when the only law that mentions human security is Republic Act 9372 or the Human Security Act of 2007, which is an anti-terrorism law to protect Filipino citizens from the dangers of terrorism and global crime, thus giving Filipinos "security" in human terms.

While the state explicitly does not use the framework of human security for its migration policies, the two-pronged strategy of human security that focuses on empowerment and protection has been the guiding principle that has shaped the migration state apparatus. The promise of migrant welfare and human security is premised on the following points: creating better policies and institutionalizing migrant state agencies, creating national laws together with bilateral and multilateral agreements on migration and in recent years, the promotion of Migration and Development initiatives. Even as the state attempts to achieve its human security goals on migration through its institutionalized agencies and initiatives, the next section will show how the state began to emphasize migrant protection while at the same time, show the limits of such attempts.

\section{Limits of human security: state policies and agreements}

As the Philippines experienced the increasing number of labor migrants and the feminization of migration throughout the 1980s and 1990s, various social problems have cropped up. These include the social costs of children with absent parents, the rising number of migrant abuses, and harsh conditions endured by the so-called Bagong Bayani (modern day heroes) (Asis et al. 2004; David 1991). This reached its peak during the Ramos administration when the twin cases of migrant worker abuse were widely reported. During 1994, Sarah Balabagan, an under aged migrant worker in Saudi Arabia, was arrested for killing her employer in self-defense. Another case was that of Flor Contemplacion, a domestic helper in Singapore, who was convicted and executed for killing a fellow Filipino domestic worker. With the realization that remittances came with social costs and that the Philippine state was helpless in offering protection to its citizens abroad, civil society organizations and feminist groups led massive political rallies decrying the policies of the state.

This led to the passing of the Republic Act 8042 or the Migrant Workers Act of 1995. This law explicitly states that the government will make the protection of Filipino migrants abroad its main priority and that it will shift its development agenda away from the export of Filipino labor to more economically sustainable development initiatives in the homeland. Although the law explicitly promises that the state will not be dependent on the export of migrant labor, succeeding administrations still continued its policy of sending labor migrants and even made the expansion of new labor markets a priority. Indeed, far from resolving the dependence on labor migration, it is still the main de facto development policy from the Marcos regime to the present administration (Eadie 2011; San Jose 2008). Although Republic Act 8042 promised to provide protection to migrant workers, most of the succeeding policies of the government focused mostly on the institutionalization of labor migration by creating specialized agencies and aggressively opening to new labor markets. This includes the creation of the Philippine Overseas Employment Agency (POEA), which processes overseas labor contracts, the Overseas 
Workers Welfare Administration (OWWA), which provides for emergency money and repatriation of Filipino migrants, and making migrant protection one of the three central pillars (together with national security and trade expansion) of the Department of Foreign Affairs.

Initially, government agencies were tasked to regulate recruitment agencies that act as middlemen between overseas jobs and potential migrants. However, with the rise of incidents of illegal recruiters and the problems brought by debt bondage, i.e., high placement fees that force migrants to give a substantial percentage of their salary to their job brokers, led the state to concentrate on regulation. While these measures, together with the introduction of pre-departure orientations and worker contracts processed through the POEA, they are often reactive and are still limited in terms of migrant protection. As the years and succeeding governments continued their policies of labor export, migrant communities and advocacy groups began to see the limitations of national-level policies, especially as migrants working abroad were not afforded external citizenship rights and were still prone to abuse. This includes problems brought about by physical and sexual abuse, human trafficking, underpayment of wages, and debt bondage.

Other than state agencies and laws, the Philippine government also enters into bilateral agreements with other migrant receiving states. Since these agreements are statelevel and official in nature, it is hoped that it will offer protection to migrant workers. One of the main pillars on how bilateral labor agreements are implemented is through the POEA. Since it started, it was initially tasked to find new labor markets and was the primary official deployment agency of the country. However, through the years it has become more of a regulatory body and is solely responsible in creating work contracts between Overseas Filipino Workers (OFW) and their employers abroad. While these contracts are transparent and have clear provisions on benefits, salaries and expected work responsibilities for the worker, in reality, these contracts are often not honored in the work place abroad. A good example is the contract between an entertainer working in Japan and her placement agency. Although the contract stipulates that she receives a certain amount as salary per month, this base salary is often deducted once the worker is abroad. Deductions that are not included in the contract can include payment for housing and transportation, uniform, clothes, and food. Also, debt payments or placement fees given to the recruitment/placement agencies are deducted from the first few months of the contract. It is this system that led to OFWs trying to renew their work contract in spite of the harsh work conditions since it is only during their second or third contract renewal/migrant journey that they have already repaid their debts and can start earning money for their families (Guevarra 2010; Rodriguez 2010; Ballescas 1992).

Another well-known case where bilateral agreements have been used to promote Filipino labor is the 2006 Japan-Philippines Economic Partnership Agreement (JPEPA). The JPEPA includes provisions for trade, financial flows, and a controversial provision called the Movement of Natural Persons (MNP). Unlike other bilateral agreements that dwell specifically on migrant labor, the JPEPA was unique in that labor migrant provisions are included in a bilateral trade agreement. The JPEPA MNP includes provisions for caregivers and nurses to enter Japan, train in Japanese health care institutions and after passing the tough licensure exams, can be allowed to work in a Japanese hospital or care institution. Many studies and reports have discussed the shortsightedness and unsustainability 
of the program (Ogawa 2012; Ballescas 2010; Takahata 2010). Although most of these studies discuss the low passing rates of the program, the high cost of training, problems of sustainability and how the program does not clearly address the underlying labor and social context of Japan's health care industry, what the JPEPA experience shows are the limitations of bilateral agreements and how they cannot provide for humane and ideal labor rights for the migrants.

This is related to the underlying geo-political positions of the two countries. Inasmuch as they provide much needed and well-trained workers and professionals for migrant receiving countries, the Philippines is in a weak position to demand for better migrant rights and protection. This is simply because receiving countries can simply go to competing and emerging labor sending countries in Asia which have lesser trained workers, but offer lower wages. Thus, bilateral agreements highlight the unequal relations of the sending and receiving countries, and how a race-to-the-bottom mentality has not brought better protection and provisions for migrants in Asia.

As the Asian region and the developing world saw the rise of labor migration flows since the 1980s, various countries have foreseen the need to establish international and regional agreements to outline the rights of migrant workers. After much discussion, the UN Convention on the Protection of the Rights of all Migrant Workers and their Families was signed in 1990. As of the 2013, only 47 states have ratified this convention. Unsurprisingly, all those who ratified the convention are sending countries, while receiving states in North America, Western Europe, and parts of Asia have not signed nor ratified.

In analyzing the previous cases, it can be said that while such international and regional forums are important and worthwhile endeavors, there is a sense that such initiatives are bureaucratic and technocratic in approach, which are mostly focused on the state level and toward government agencies. This section highlights how policies, whether they are national, bilateral and regional level, are arguably reactive and shortsighted. The limits of government policies are demonstrated, as well as how implementation on the ground is often a jarring problem.

\section{Limits of human security: migration and development initiatives}

As the state is attempts to achieve human security through its migration policies and laws that promise migrant protection, the previous section has shown the limits of statelevel policies. Even as the state realized their limitations, they have offered a new alternative that aims to maximize the outcomes of migration and using its remittances for the development of the country. This rationale is exemplified by the new migration and development paradigm that is embraced by both labor migrant sending and receiving countries.

Initially, Castles (2009) used the term "migration and development mantra," which is based on Kapur's idea that remittances have become a "new development mantra" in which governments and officials believe that money sent home by migrants can be a recipe for local, regional and national development (Kapur 2003). This notion of a "new mantra" assumes that: (a) migrant remittances can have a major impact on the economic development of countries of origin, (b) migrants also transfer home skills and attitudes-known as "social remittances" that support development, (c) "brain drain" is 
being replaced by "brain circulation," which benefits both sending and receiving countries, (d) temporary (or circular) labor migration can stimulate development, (e) migrant diasporas can be a powerful force for development through the transfer of resources and ideas and (f) economic development will reduce out-migration (Castles 2009: 457-458).

Through the years, migration and development has grown in popularity and acceptance, leading both sending and receiving nations to adopt it within their migration policies and policy agendas. After years of sending countries decrying the lack of protection of its migrant citizens while working abroad, while receiving countries meanwhile argue that the movement of unskilled labor causes social costs, ranging from added social welfare costs to increase in crime and problems of intercultural relations, the migration and development agenda promises to solve this issue by addressing the concerns of both migrant sending and receiving countries. Central to this paradigm is the assertion that bringing development to the sending countries, through overseas development assistance and maximizing remittances for local development agendas will address the push factors of migrants, leading them finally stay in their home countries for domestic employment and relieving the pressure for receiving countries of controlling foreign migrants within their borders (Haas 2006). Furthermore, it is also beneficial for migrants themselves since migration and development initiatives will help promote the development of social remittances or the necessary skills (Levitt 2001). Another avenue where migration and development agenda is being promoted is through the creation of the United Nations-initiated Global Forum on Migration and Development (GFMD). Created in 2007 in order to address the lack of support for the 1990 UN Convention on the Protection of the Rights of all Migrant Workers and their Families, the GFMD aims to bring the tenets and gospel of migration and development to both migrant sending and receiving countries.

While there are yet definitive studies that show the positive impact of the migrationdevelopment agendas beyond citing its potential, many studies have shown its limitations. Castles (2011, Castles and Wise 2007) point out that in discussing the theoretical and conceptual basis of migration and development, several questions should be raised: for whose benefit is this migration and development agenda, for the state or the migrants? What kind of development does migration and development entail? Oberoi (2010) supports this line of inquiry when she explains that migration and development agendas are state-centric and concentrate on the perceived benefits that states can gain from remittances and controlled migrant flows. This is especially true with migration and development assertions that circular and temporary migrant flows are more beneficial in the long term, since migrants continue to send remittances to their home countries, prevent the loss of labor through brain drain while receiving countries are not burdened by the social costs of family reunification of the migrant worker in their new adopted country. Oberoi argues that "the migrant, however, is reduced in this conceptualization to a commodity or unit of labor, able to be shuttled around the world at will, and unable often to enjoy such fundamental rights as the right to family life" (2010: 256-257).

The debate on migration and development can also be discussed in the process making of the UN GFMD. While the forum includes the participation of various stakeholders for issues on migration and development, from states, government agencies, civil society groups and academics, there was a sense that the forum was more of tentative 
discussions rather than aiming to create concrete policies and regional agreements that might have a more clear impact (Rother 2009). Furthermore, since the GFMD is a purely consultative, non-binding and limited to only inter-government agencies, civil society organizations and migrant groups are excluded from the consultative process. Since the main participants are the managers of state migration policies and exclude migrants themselves, there is a sense that human rights and the well-being of migrants are not in the forefront of the process (Roldan and Gasper 2011).

After discussing the conceptual limitations and the practice of migration and development in the international forum, other studies show the limits of such agendas as they are practiced on the ground. In particular, the problem of economic sustainability of migration and development programs are raised. This includes the criticism that the migration and development paradigm merely is used by the Philippine government to rationalize the expansion of its labor export policies and relegating its promise of bringing economic development and domestic employment in the Philippines (Ibon 2009; Weekley 2004; Tigno 1990). These are valid concerns and have precedence. While the Philippines already has programs under the National Reintegration Center for Returning OFWs to address the problems of reintegration through skills retraining and small business seminars for those who want to work after their migrant journey, these programs are often short-sighted and does not address the underlying issues of families becoming dependent to remittances and lack of employment opportunities at home (NRCO 2009, 2011). Asis explains the logic behind the relative success of migrant remittances and how in spite of this, limits of migration and development agendas are still present:

The Philippines is also successful in terms of remittance inflows from its overseas population. But beyond the social mobility experienced by the families of migrants and the community projects supported by migrants' collective remittances, the development impacts of migration are not that evident. Migration may be one of several strategies to promote development (specifically, employment generation), but it cannot suffice as a major development strategy (Asis 2007: 197).

For the Philippines, the benefits of labor migration are undeniable. Migration outcomes for some families and hometown communities have been successful. However, the dependence to labor migration has led the succeeding generations to follow the footsteps of their OFW parents. Indeed, migration and development initiatives still do not address underlying push factors and economic dependence to remittances, both in the state and household level. This is perhaps the main critical point that needs to be raised on migration and development agendas. While migration and development initiatives are important, they should not be seen as catchall solutions or panaceas to the problems of migration. In order to address the challenges of migration, the larger issues of migrant representation, empowerment and long-term development need to be addressed to reach genuine human security for migrants. Castles and Wise explains that:

The general conclusion on migration and social transformation is therefore that there is great potential for outcomes beneficial to sending country populations, but the conditions for realizing these are complex and difficult. Strategies of "remittance-led development" seem simplistic and naïve. Migration alone cannot remove structural constraints to economic growth, social change and greater democracy. 
There is a need for broadly based long-term approaches that links the potential benefits of migration with more general strategies to reduce inequality and to improve economic infrastructure, social welfare, and political governance (2007: 281).

The previous discussion has shown how migration and development agendas are often state-centric and quite to the contrary, do not fully implement the rationale of human security for migrants, namely that of migrant protection and empowerment. This limitation is discussed further in the next section.

\section{Towards a national dialogue on migration}

As the state grew more dependent on labor migration and remittances, it realized that it needed to offer more than token promises in order to develop policies that guarantee migrant protection and empowerment. The previous sections have shown how the state attempted to achieve human security through its institutionalized state policies and policies on migration and development. Even as the state promises to offer protection and empowerment, previous attempts have been limited, reactive, and shortsighted which suffer from problems of proper implementation and sustainability. However, instead of concentrating on the limitations of human security, this paper argues that human security can still be reached through the building of a national dialogue on migration. This national dialogue will be able to empower and protect migrants since it includes all stakeholders-from the state and its agencies, civil society organizations, and migrant groups. Through this national dialogue, a consensus can be reached that places the issue of migrant protection and empowerment into the public consciousness. This will then become an important factor in bringing successful policies that addresses human security for migrants in both the sending and receiving states.

Migration is one of the biggest phenomena that have made a significant impact on Philippine social life. Initially limited to blue-collar agricultural workers and nurses to the US during the US colonial period until post-war independence, labor migration was introduced as a stopgap measure to the unemployment and balance of payment problems of the Marcos regime. However, as the state and families in the homeland began to become more dependent on remittances, labor migration has expanded to new labor markets and new work opportunities, ranging from blue-collar construction jobs to white-collar professional work and seafarers all across the globe.

Migration has become so engrained in the Philippine psyche that migrants are called as Bagong Bayani (modern day heroes) as homage to their sacrifice and bravery (Rodriguez 2010). In spite of the social costs and problems brought by massive labor movements and the feminization of migration, the Filipino people began to accept the reality of migrant life. This has brought about what Asis describes as the "culture of migration" (2006b). This culture sees the migrant journey as an adventure, as desirable and one's patriotic duty all the while knowing of the hardships and pitfalls of work abroad. Even during the peak of political upheavals and scandals, Filipinos seem to see migration as an alternative solution to the problems of development. Seeking to take "flight instead of to fight", Filipinos now prefer to go abroad and see it as a solution to the perennial pessimism in the homeland (SWS 2004).

Although majority of Filipinos want to work abroad and see work outside of the country as desirable, it does not follow that they are unconcerned apathetic citizens. 
Inasmuch as migrant groups, advocacy groups, and activists counter the narrative that all OFWs are Bagong Bayani and argue that they are in fact martyrs, the larger Philippine society are quite conscious of the problems of migration and as such, have demanded more opportunities for social protection and political participation even while they work away from their homeland.

A clear manifestation of this growing dialogue on migrant rights has been the passing of important migrant legislation that has direct benefits to the plight of the Filipino migrant. These include the Republic Act 8042, the so-called Magna Carta for Overseas Filipinos of 1995, which made migrant protection into a national policy; Republic Act 9189 or the Overseas Absentee Voting Bill Act of 2003, which allowed for migrants to vote for national level candidates; and Republic Act 9225, or the Citizenship Retention and Re-acquisition Act of 2003, which allows for dual citizenship.

While the state's migration policies have often been criticized as reactive, major bills and laws on migrant rights that have passed has shown how migrants together with various civil society groups and stakeholders can influence policy and lawmakers. These venues for dialogue can only get better through migrant labor rights awareness campaigns and participation in political processes such as overseas absentee voting. Indeed overseas voting has the potential to influence political candidates since they can form a block vote and demand concrete political platforms on migration that go beyond token campaign promises. Furthermore, emerging political parties that campaign on behalf of migrants such as Migrante, Akbayan and other transnational political groups are now contesting the party list positions in the Philippine Congress. This could potentially mirror the experience of Mexico wherein migrant representatives are elected in their legislatures.

Although critics of labor migration and activists might counter the notion that Philippine society has accepted the culture of migration, the logic of sending migrants, and naively support migration and development initiatives, the fact that legislation and moves to represent the migrant voice in the legislature in the past two decades has shown that the nation is taking positive steps in reaching a national dialogue which can lead to a consensus on migration issues.

\section{Conclusions}

Most scholars highlight the appeal of human security. Indeed in our globalizing world where the limits of state-level and state-centric policies are clearly felt, human security with its people-centered approach that offers protection and empowerment has found a resonance in one of the most contentious and challenging realms of our global society, that of international migration. However, while both government officials and scholars point out the benefits of human security for migration, most of the existing literature has focused on its potential and lacks substantive studies on how human security is actually practiced on the ground. By using the Philippines as a case study, this paper shows how the state is attempting to achieve human security for its citizens through its migration policies, institutionalized migrant agencies, and the introduction of the migration-development agenda. This paper then shows the limits of such migrant centered policies.

Upon closer analysis, these state initiatives were limited since although these policies attempt to become "migrant-centered", it is still the state interest and state-level 
concerns that are given importance. Furthermore, the promise of migration and development initiatives is also limited given that it is often seen as a cure-all panacea to the problems of migration, while ignoring the larger questions of genuine long-term development and the relative weakness of the Philippine state in international affairs to fight for its migrants' welfare and rights.

In order to work towards genuine human security for migrants, this paper argues that the strategy of human security, that of being people-centered and empowerment, should be reiterated by building a national dialogue on migration. By including all stakeholders from state officials to civil society organizations and migrant organizations, genuine human-centered policies and legislation on migrant rights can be secured for the Filipino. Furthermore, the importance of representation and participation through the reaching of a national consensus can benefit not only migrant sending countries, but also above all migrant receiving countries as they debate on the merits and challenges posed by migrants at their gates. While they may assume that building human security and creating development for the sending countries will address the pressures of migrants wishing to enter their borders, it does not consider how their changing demographic and market conditions actually need the entry of such unwanted labor. By building a national dialogue on migration, long-term and humane migration policies can be reached that address the human security of both the migrant and the citizens at the home and host countries.

Compliance with ethical guidelines

Competing interests

The author declares no competing interests.

Received: 13 July 2015 Accepted: 2 September 2015

Published online: 08 September 2015

\section{References}

Asis, Maruja M.B. 2007. How international migration can support development: a challenge for the Philppines. In Migration and development: perspectives from the south, ed. Stephen Castles, and Raul Delgado Wise, 175-202. Geneva: International Organization for Migration.

Asis, Maruja M.B. 2006b. The Philippines' culture of migration. Migration Information Source. http://www.migrationinformation.org/Profiles/display.cfm?id=364. Accessed 28 Nov 2007.

Asis, Maruja M.B., Shirlena Huang, and Brenda S.A. Yeoh. 2004. When the light of the home is abroad: unskilled female migration and the filipino family. Singapore Journal of Tropical Geography 25(2): 198-215.

Ballescas, Maria Rosario Piquero. 2010. Sharing care: economic partnership agreement and beyond. Bulletin of Kyushu University Asia Center. 5:209-222.

Ballescas, Maria Rosario Piquero. 1992. Filipino entertainers in Japan: an introduction. Quezon City: The Foundation for Nationalist Studies.

Castles, Stephen, De Hass, Hein, and Mark J. Miller. 2014. The age of migration: international population movements in the modern world. New York: Palgrave Macmillan Limited.

Castles, Stephen. 2009. Development and migration or migration and development: what comes first? Asian and Pacific Migration Journal. 18(4): 441-471.

Castles, Stephen. 2011. Bringing human rights into the migration and development debate. Global Policy. 2(3): $248-258$.

Castles, Stephen, and Raul Delgado Wise (eds.). 2007. Migration and development: perspectives from the South. Geneva: International Organization for Migration.

Commission on Human Security. 2003. Human security now. New York: Commission on Human Security.

David, Radolf S. 1991. Filipino workers in Japan: vulnerability and survival. Kasarinlan. 6(3): 9-23.

Eadie, Pauline. 2011. Philippines overseas foreign workers (OFWs), presidential trickery and the war on terror. Global Society. 25(1): 29-47.

Edwards, Alice, and Carla Ferstman (eds.). 2010. Human security and non-citizens: law, policy and international affairs. Cambridge: Cambridge University Press.

Graham, David T., and Nana K. Poku (eds.). 2000. Migration, globalisation and human security. London and New York: Routledge. 
Guevarra, Anna Romina. 2010. Marketing dreams, manufacturing heroes: the transnational labor brokering of Filipino workers. New Jersey: Rutgers University Press.

Haas, Hein de. 2006. Turning the tide? Why'development instead of migration' policies are bound to fail. Working paper 2. International Migration Institute, University of Oxford.

Ibon International. 2009. The myth of migration for development. http://edm.iboninternational.org/2009/july-august2009/247-the-myth-of-migration-for-development. Accessed 8 Sept 2011.

Kapur, Devesh. 2003. Remittances: the new development mantra? G-24 Discussion Paper Series.

Levitt, Peggy. 2001. The transnational villagers. Berkeley: University of California Press.

National Reintegration Center for OFWs. 2011. National Reintegration Center for OFWs Website. http://www.nrco.dole. gov.ph/. Accessed 11 April 2011.

National Reintegration Center for OFWs. 2009. Exploring developmental potential of remittances through the Philippine reintegration program for overseas Filipino workers. Discussion paper for the regional dialogue on enhancing the development directions in the utilization of remittances, Rome, Italy, May 19-20, 2009.

Oberoi, Pia. 2010. Empowering migrants: human security, human rights and policy. In Human security and non-citizens: law, policy and international affairs, eds. Edwards, Alice and Carla Ferstman, 227-272, Cambridge: Cambridge University Press.

Ogata, Sadako. 2002. From state security to human security. Ogden Lecture Brown University 26 May 2002.

Ogawa, Reiko. 2012. Globalization of care and the context of reception of southeast Asian care workers in Japan. Southeast Asian Studies. 49(4): 570-593.

Philippine Overseas Employment Administration. 2010. Compendium of overseas employment statistics. http://www. poea.gov.ph/stats/statistics.html. Accessed 21 Jan 2013.

Rodriguez, Robyn M. 2010. Migrants for export: how the Philippine state brokers labor to the world. Minneapolis: University of Minnesota Press.

Roldan, Bernice, and Des Gasper. 2011. The global forum on migration and development: all talk and no action or a chance to frame the issues in a way that allows you to move forward together? In Transnational migration and human security: the migration-development-security nexus, ed. Thanh-Dam Truong, and Des Gasper, 239-256. Berlin: Springer-Verlag.

Rother, Stefan. 2009. Inside-outside or outsiders by choice? Civil society strategies towards the 2nd global forum on migration and development (GFMD) in Manila, 95-107. ASIEN AKTUELL 111. April.

San Jose, Benjamin A. 2008. From Bagong Bayani to global Filipino: legitimizing the intensification of Philippine migration. Master's Thesis. Department of International Political Economy, University of Tsukuba.

Social Weather Station. 2004. SWS 3rd quarter survey. September 14, 2004. http://www.sws.org.ph/pr140904.htm. Accessed 7 Jan 2008.

Takahata, Sachi. 2010. Immigrant Filipino caregivers in Japan: their motivation for license acquisition, and some issues at their workplace. Kansai Sociological Review. 9:20-30.

Tigno, Jorge V. 1990. International migration as state policy: the Philippine experience as model and myth. Kasarinlan. 3rd and 4th Quarter, 73-78.

Truong, Thanh-Dam, and Des Gasper. 2011. Transnational migration and human security: the migration-developmentsecurity Nexus. Berlin: Springer-Verlag.

Tyner, James A. 2000. Migrant labour and the politics of scale: gendering the Philippine state. Asia Pacific Viewpoint. 41 (2): $131-154$.

Vietti, Francesca, and Todd Scribner. 2013. Human insecurity: understanding international migration from a human security perspective. Journal on Migration and Human Security 1(1): 17-31.

Weekley, Kathleen. 2004. Saving pennies for the state: a new role for filipino migrant workers? Journal of Contemporary Asia 34(3): 349-364.

World Bank. 2011. Migration and remittances factbook 2011, 2nd ed. New York: World Bank.

\section{Submit your manuscript to a SpringerOpen ${ }^{\circ}$ journal and benefit from:}

- Convenient online submission

- Rigorous peer review

- Immediate publication on acceptance

- Open access: articles freely available online

- High visibility within the field

- Retaining the copyright to your article

Submit your next manuscript at $\boldsymbol{\nabla}$ springeropen.com 